\title{
State and Revolution
}

\author{
Nations, Tribes, and Lineages
}

\begin{abstract}
Within this structure of society based on kinship groups the productivity of labour increasingly develops, and with it private property and exchange, differences of wealth, the possibility of utilizing the labour power of others, and hence the basis of class antagonisms.
\end{abstract}

-FRIEDRICH ENGELS

During the second term of Bolivian president Evo Morales, at a time when the proceso de cambio was amplifying its reach and voting base, an unusual dispute begun to unfold within the Bartolina Sisa National Confederation of Peasant, Indigenous and Native Women of Bolivia (simply known as "Bartolinas"), the largest female organization in the country and a structural component of the proceso de cambio. ${ }^{1}$ During a national assembly of the confederation, members of the associations of coca growers from Bolivia's tropical regions proposed to homogenize the dress of all Bartolinas by replacing the traditional Andean female shawls, meticulously decorated and colored according to the region or even community of provenance, with a standard blue shawl. The blue shawl was an attempt to give the Bartolinas a recognizable national uniform for the vast heterogeneity of their membership, which included women from multiple ethnic groups and different regions of the country. But above all, blue was the color of the ruling party-the

1. Literally the "process of change", the proceso de cambio is officially known as Bolivia's "democratic and cultural revolution" and usually identified with the leadership of President Evo Morales from 2006 to 2019. As per many revolutionary processes, if the idea of the proceso de cambio was initially associated with a series of indigenous and popular organizations taking center stage in the historically exclusive Bolivian politics and society, it has been gradually identified with a project defined from the state and structured around the figure of Evo Morales. While this book was in press Morales was ousted from power, feeding a debate as to whether the proceso de cambio had come to an end. A specific analysis of these last events will not be produced in this text. 
Movement Toward Socialism, MAS-therefore reasserting the Bartolinas' role, affiliation, and prominence in Bolivia's proceso de cambio.

The proposal was received with bemusement by highland Aymara women from the Bolivian plateau. In fact, most of them, in the classic highland style, did not even react or reply to a proposal that sounded purely absurd. For these women, who wear shawls, decorations, and power items sometimes passed down from one generation to another, the "blue shawl" just signaled an ontological confusion about what the "revolution" is and ought to be. To replace the traditional shawls signaling the specific stories and colors ("flags") of their ancestors with a blue shawl identifying the ruling party was to throw the baby out with the bathwater! The party was referred to as an "instrument," not an end in itself, for multiple and articulated groups and communities to gain access to the official political sphere and to bend it to their rules and forms; it was a "son procreated by multiple indigenous associations," a mere "political arm" of their communities and organizations (García Yapur et al. 2014; Arbona et al. 2016). This seems to foreground a notion of "revolution" as not necessarily associated with increasingly unified salaried workers but as a political transition toward the segmented networks and logics of local political organizations. Although this is often represented as a tendency of local groups to get stuck in traditional political logics and the defense of particularistic interests, as opposed to national ones (García Linera 2015b), what seems to emerge here is a notion of articulated and networked indigenous groups that precedes and surpasses the homogeneous notion of party and state. In other words, for Aymara women communal political mobilization was not based on the notion of a symbolic and standardized blue shawl homogenizing and "nationalizing" local indigenous groups but rather on a multicolored fabric of patched localisms "indigenizing" the party, the nation, and the state.

In the political analysis of revolutionary transformations, indigenous tribes, kinships, and lineages are often associated with particular, local forms and counterposed to universal structures of political organization such as the state, the party, and the trade union. As apparent in the title of Lenin's masterwork (Lenin [1917] 2014), the notion of revolution has been inextricably bound to the idea of the state. Words like tribe and clan have been problematically associated with traditional forms of sociopolitical organization that ought to be overcome in order to produce a transition toward modern states or "democratic" political formations. A series of canonical narratives and conceptualizations of revolution have not only identified the party and the state as strategic tools and instruments in the consolidation and coordination of revolutionary transformations but have also conceived them as unitary, wider, universal agents of articulation of localized political cultures in order to develop a truly emancipatory political consciousness.

In this chapter, we aim to open up these assumptions by using the ethnographic realities anthropologists have been researching, with a focus on revolution 
through the sociopolitical framework of indigenous tribes, lineages, and kinship alliances. In other words, we are interested in what happens to the conventional and modern narratives about state and revolution when we place them in contexts where the political is often defined by the intersection of tribes, lineages, and ancestors. Also, we look at the specific concepts and ideas of "revolution" developed from the political logics of local tribes and clans.

Although some anthropologists have discouraged the use of terms such as clan and tribe due to the burden of sociopolitical traditionalism intrinsically attached to them, others have actually emphasized the strategic role of these forms of organization to solve conflicts and organize populations, accomplishing a role similar to that typically accorded to the state and even giving shape to other notions of nation. Throughout this chapter and the entire book, we will maintain the use of the word tribe not so much to emphasize its anchorage in political tradition but rather to highlight its proactive role in outlining specific revolutionary notions and practices.

"WORKERS OF THE WORLD, UNITE!": REVOLUTION AS A UNIVERSALIZING PROJECT

At the inception of the Arab Spring, which appeared to coincide with the mushrooming of a series of unconventional, populist, and anti-establishment movements (Podemos in Spain, Syriza in Greece, Occupy in the United States), an intellectual conflict arose between popular and controversial philosopher Slavoj Žižek and US-based, Iranian intellectual Hamid Dabashi-a skirmish that ended up involving several other postcolonial theorists. Following Marx and the notion that even the most local and particular problems remain embedded in the wider global system, Žižek (2013) affirmed that in the case of the Arab Spring or the anti-establishment movements the particularization of protests and the inability (or unwillingness) to present the protests as a global, universal, and systemic revolution appealed to the defenders of the status quo. Žižek emphasized how the lack of a common coordinating body to guide the multiple political mobilizations tended to present the upheavals in terms of a series of separate local problems that ought to be alleviated rather than of a universal threat against the general order.

In contrast with Žižek, Hamid Dabashi (2012) argued that in order to understand the Arab Spring one has to think outside of the conventional box of the creation of the central representative party and the conscientization of the masses, while placing the left and Žižek's notions of what a revolution ought to be as part of a hegemonic régime du savoir. Not always convincingly, Dabashi depicts the Arab Spring as the retrieval of an Arab political possibility of being outside of the conventional binary oppositions between Islam and the West-a new dimension of 
politics that conventional narratives of revolutionary practices end up obfuscating. A bit too hastily associating the Arab Spring with the end of postcolonialism and its regime of knowledge, Dabashi asserted that in the world beyond Christian dogma people are not born in a state of sin, and as there is no original sin, there is no final forgiveness and therefore no grand illusion, no master narratives of emancipation, no universal authorities and organizations to redress a flawed individual. What Dabashi seems to be saying is that universalistic notions of revolutionary transformation are often embraced in order to discard locality-based understandings of political action without even considering that those universalistic notions are themselves anchored in a specific and localistic political culture (cf. Badiou 2003).

In Europe, a long philosophical tradition has identified unity and universalism as strategic tools of political emancipation and transformation. What we strive to show here is how these currents of thought have come to clash with and even conceal the political relevance of fragmentary forms of political organization such as tribes, clans, and ethnic groups, supposedly unfit for thorough and global processes of radical transformation. Both in Marxism and modern liberalism, for instance, revolution is understood as a universalizing project, moving away from the particular. Local cultures and beliefs may naturalize undemocratic forms of political subjugation, preventing people from perceiving the true nature of their social and economic situation (Marx [1867] 2011), and reproducing and reifying forms of power that curtail individual liberties (Skinner 2008). Liberalism, for example, has been fostering processes of "disembedding" the individual from local particularities - family, kinship, locality-and from the burden of illiberal tradition in order to make the subject a free, agentive, and creative citizen able to freely sell his / her labor on the market (Polanyi 1959; Scheele 2007).

In the internationalist and socialist tradition, there has been a constant emphasis on the union of all workers of the world against the old regime (Marx and Engels [1848] 2005), stressing the necessity both of a certain degree of homogeneity among the fighting masses and of overcoming traditional and fragmentary organizational structures (Marx [1852] 2008; Wolf 1969; cf. Stern 1987). Particularistic and localistic interests may undermine the strength of the workers' movement but also be detrimental to the expression of the universal and general interest (Hegel 1999; García Linera 2015b). Universal structures such as the party, the union, and the state are therefore required to overcome the fragmentation of workers bound up in multiple localities, affiliations (clan, tribe, kinship, family), and beliefs and to integrate a multiplicity of groups while channeling them toward a common emancipatory horizon.

According to this view, peasant masses or indigenous peoples immersed in particularistic beliefs and attached to traditional, localized, and fragmented forms of political organization (from culture to family, from kinship to ethnic 
organizations) were not quite able to generate a new, creative revolutionary vision and program of thorough political liberation (Moore 1966; Wolf 1969; Gluckmann 1963). Peasants and indigenous groups were either the parochial initiators of revolts or simply reacting to changes determined by powerful external forces (Stern 1987: 6), but they were fundamentally unable to imagine a global, systemic transformation.

Despite their prominence in strikes and insurgencies (cf. Wolf 1969), peasant groups, indigenous communities, or Middle Eastern tribes were said to lack political discipline and organization (cf. Chakrabarty 1994; Chatterjee 1993; Guha 1983). Their organization was weak, with the structural conditions, or even local modalities of associations-often based on a ritualized systems of authority or rotational forms of leadership (cf. Ávila Molero 200o)-hindering peasants or indigenous groups from fully grasping the discipline and functioning of trade unions and politics more generally (cf. Chakrabarty 1994: 168). They supposedly lacked a disciplined body of workers subjected to a series of institutional controls, from the rights and obligations of membership to the regular meetings. Therefore, peasants and indigenous groups were considered unable to express themselves ideologically and politically (Zavaleta 2011) and needed to be educated and organized by the avant-garde of the party in order to access and effectively participate in the realm of the political (Chakrabarty 1994: 169).

If we take the example of the French Revolution, the whole revolutionary endeavor is driven by the consolidation of a wider, unitary, and universal organizational structure that could supersede local affiliations. The French Revolution has been conceptualized as bringing about the concept of nation as a new social unit, a whole new political community, disentangled from previous and particularistic cultural anchorages, which was one and indivisible and where sovereignty resided (Sieyès 1989; Ricciardi 2003). Moving away from particularism and toward universalism, the nation was to become a universal entity by replacing the God-like monarch through revolution. The French Revolution not only crystallized a nationalist program but also a new political unit (the nation) to which people felt ultimate loyalty. When Louis XIV convened the General Estates during the financial and political crisis in 1789,140 years after the last time they were convened, the representatives of the Third Estate proclaimed its organization to be a national assembly that was one and indivisible and where the sovereign will resided. Instead of the king-God, the people/nation was now the sovereign entity. Not only would this lead to the revolutionary slogan of "the people as sovereign" but also to the constitution of the nation-state as a universal revolutionary entity. With some exceptions, the state as the embodiment of a national community would become a compulsory stage in the evolution of political formations and in their possibility to aspire to wider and greater political changes (see also Geertz 1973C, 1973d). In the following section 
we explore the role attributed to the state among political theorists in processes of radical political transformation.

\section{THE STATE AS UNIVERSALIST}

\section{AND REVOLUTIONARY AGENT}

The role of the state in revolutionary processes has often been associated with the expression of universal and general interests versus either the chaotic revolutionary masses or the interests of the few. For Hegel (1999) the concept of revolution is characterized by a complex movement or tension which implies, on the one hand, moving the principles of revolution inside the state and, on the other, progressively adapting the relationship between the constitution and the people in order to educate the latter about the changes of spirit (Ricciardi 2003). In other words, once the revolution produces a multiplicity of new rights, these rights ought to be composed within an autonomous political unit that the revolution itself, given its chaos and multiplicity, is not able to generate. Robespierre's frictions and ultimate rupture with the sans-culottes (Robespierre 1989) was a consequence of the latter's understanding of themselves as sovereign, implying that the revolutionary government is a simple agent or representative whose ability to take autonomous decisions can be denied at any moment. In Robespierre's opinion, there is no space for direct democracy-and particularly for the constant movements and oscillations that the sans-culottes imposed on society and politics-since "democracy is a state" (1989: 128) where the sovereign people, guided by laws, operate.

A similar dialectical relationship between state and revolution has been employed to theorize recent revolutionary movements, for instance by the former vice president of the Plurinational State of Bolivia, Álvaro García Linera, in relation to the proceso de cambio. García Linera (2015a, 2017) affirms that revolution is like a magmatic force that explodes, manages to break the Earth's crust and erupts into the world, flattening and reshaping everything it encounters in its path (2017: 15). If in its inception this magmatic force floods the world with indomitable power, it also slowly begins to cool down and solidify, having irreversibly transformed the surface of the Earth-but only until the next eruption. For García Linera, revolution as a magmatic force (living labor) dramatically alters the geological and cosmological coordinates and eventually condenses into a new state (dead labor), literally a new state with a new composition and a new monopoly of coercion and legitimacy. As a pragmatic Marxist, García Linera envisions revolution as a creative multiplicity. If, on the one hand, it constitutes a necessary force to transform the world, it presents, on the other, the risk of undermining itself due to the self-destructive tensions among local interests and the multiplicity of its composition that may jeopardize the functioning of revolutionary politics. 
To avoid the latter risk requires the constitution of an institution (the state) that acquires the role of administering the "general," not the local, and unifying and coordinating local actions.

For Lenin ([1917] 2014), the state was the expression of the interests of a specific class, namely the bourgeoisie in capitalist society, and a machine through which these interests were naturalized so that they appeared to be the interests of the whole nation. Instead of envisioning the state as a means to reconcile the interests of different classes, Lenin affirmed that the state can only be the organ of the rule of a definite class which cannot be reconciled with its opponent. Following Engels, in State and Revolution Lenin proposes two stages in the process of transformation of the bourgeois state. The first stage is the so-called "dictatorship of the proletariat" that follows the socialist revolution and that implies the seizing of state power by the proletariat and turning the means of production into state property. For Lenin, the dictatorship of the proletariat is a temporary solution by which the working class will use the state to rebalance centuries of political injustice and as a tool to "expropriate the expropriators"-the bourgeoisie-of their accumulated politico-economic privileges. In the case of the Soviet Union, for Lenin the idea of the dictatorship of the proletariat constituted a necessary path to fill the gap of the politically backward peasant masses who had been exploited for centuries by landlords and living in a serf-like condition. Lenin referred to the political backwardness of peasants and the necessity of a leading political authority able to show them the path of emancipation. In other words, a state-bound vanguard party would lead the way in the process of political emancipation of the peasants.

In a second stage, once a political equilibrium was achieved or once all class distinctions and antagonisms were abolished, the proletarian state-not the bourgeois-will "wither away" in the same way as any other naturalized political ideologies. If in a class society, the exploiting class would need the state for the maintenance of the conditions of production, when the state becomes the real representative of the whole society, it renders itself unnecessary and can therefore "wither away."

Although in different forms, the conquest and manipulation of state power became a central feature of revolutionary endeavors. The state was a fundamental step, tool, or instrument through which revolutionary societies were shaped. From the Soviet Union to China, or with respect to the guerrilla movements in Cuba and Angola, the state has been positioned as the vantage point from which to radically transform society. In the revolutionary processes of the Soviet Union, China, and Cuba, by taking charge of planning the economy, administering the means of production, housing, and the education and "conscientisation" (Freire 1970) of the masses, the "new" state would become an instrumental tool in the transformation of the previous regimes (Yurchak 2006; Holbraad 2014; Cheng 
2009). An exception to this role of the state in revolutionary processes is constituted by the analyses and proposals of anarchism that, despite being largely outshone by Marxism-Leninism in revolutionary practices, have also inspired radical movements in their transformative endeavors.

\section{"Canonical Exceptions" to the State as the Center of Revolutionary Transformations}

Probably the most profound point of disagreement between Marxism and anarchism was centered on the different conceptions of the state. As we have seen, while for Lenin the state was an instrument for the exploiting class to exert and reproduce its domination, for anarchists the state constituted the structure engendering a class society (Bakunin 1971). Therefore, while Marxists promoted the conquest of the state and the constitution of a workers' state that would progressively wither away, anarchists aimed their revolutionary upheavals at the abolition of the state, as the state was seen as reproducing a layer of bureaucrats and salaried employees and a system of class distinction. For Bakunin, revolution is real while in the hands of the masses, but when it begins to be managed and concentrated in the hands of a few ruling individuals it becomes reaction. While Marxism-Leninism envisioned a transitional stage between capitalism and a mature communist society that included a workers' state in the form of the "dictatorship of proletariat," Bakunin (1971) was adamant in rejecting the establishment of any kind of state, which was to be supplanted by federated communal militias, self-governed institutions, and nonhierarchical free associations in the defense of revolution. For Bakunin, the revolutionary option implied moving immediately, without transition, to a mature communist society that would be distinguished by the absence of the state.

A revolutionary movement that has likely capitalized on some of Bakunin's ideas is Mexican Zapatism. The outbreak of the Zapatista rebellion in 1994 drew the world's attention to the plight of indigenous peoples in the region of Chiapas in the south of Mexico and particularly to the profound social and economic transformations of the region as a consequence of the recent neoliberal restructuring of agriculture (Collier 1994, 1998). The Zapatista Army of National Liberation declared war on the Mexican state and the corporate and military groups operating in the region.

Following the structural adjustment policies implemented by the Mexican state, the genuine process of political radicalization of Chiapas's indigenous peoples was accompanied by pan-indigenous groups and organizations with Liberation Theology leanings (Leyva Solano 1994) as well as by Mexican leftists and progressives with close links to early twentieth-century Zapatist ideology (Earle 1994). The distinctive combination of Mayan political elements and the ability of the movement to elicit global attention by means of a transnational communication strategy (Nash 1997) not only led to a mushrooming of studies and publications 
on the topic but also ended up articulating a "transnational zapatism" that likewise became crucial in the political and ideological definition of the rebellion (Johnston 2003; Keck and Sikkink 1998), articulating the indigenous dimension with alter-globalization and anti-neoliberal movements.

Instead of a hierarchical structure of power with a transcendent state or party coordinating the masses and unifying local action, drawing on supposedly lessstructured indigenous notions of politics the Zapatistas were "led" by a subcommander placing society/community above rather than below the ruler and grounding the idea of the ruler on the notion of "ruling by obeying" (Holloway 2002; Mignolo 2002; cf. Clastres 1977), implementing indigenous notions of democracy founded on local practices and organizations (Mignolo 2002). However, Zapatista communiqués were often skillful in reconciling indigenous notions of politics with more conventional leftist ideologies, swapping the particular narratives of ethnic liberation for the grand narrative of human emancipation-therefore universal and nonparticular-and the fight against neoliberalism. On the one hand, such a strategy was successful in foregrounding the Zapatist rebellion at the center of academic and public political discussions far away from Chiapas. On the other hand, in these same media discussions the nucleus of the Zapatist rebellion appeared more and more focused on the charming and metaphoric reasoning of subcomandante Marcos than on the indigenous issues at the heart of the rebellion.

Instead of building on existing political models and colonial practices, Marcos's ideas about Zapatism placed the movement as articulating a "new" notion of politics and revolution with global valence that was particularly appreciated by both postcolonial scholars and global activists. John Holloway $(1996,2002)$ describes how Zapatistas do not so much aspire to change the world by taking power, but to make the world and politics anew, therefore questioning a traditional attitude of the left that positions the state (and its conquest) at the center of radical transformations. Instead of changing society by becoming powerful, Zapatistas attempt to dissolve relations of power altogether. Citing Marcos and other Zapatista leaders, Holloway explains how Zapatism constitutes a rupture with a serious and rigid revolutionary left whose emphases on dedication, sacrifice, and responsibility have engendered processes of suppression of the self and fragmentation of the person (Holloway 1996; see also Holloway and Pelaez 1998) required by the winning of state power. In so doing, Holloway reconciles Zapatism with the criticism of former student rebels of the 1968 protests, who took an explicit political stance against the coercive powers of the state, the party system, and societal norms that curtailed personal freedoms and processes of social liberation (Fusaro 2012). But it also emphasizes how the Zapatistas do not constitute a conventional revolutionary group but a "community in arms" (cf. Zibechi 2006), dispensing with a series of orthodox notions and models of revolutionary operation. 
Possibly, the Zapatista movement constitutes an attempt to reconcile the specificity of indigenous political notions of revolution with universal/global/ transnational movements and politics, somehow replacing the mandatory conquest of the state with the creation of a transnational organization that attempts to control and paralyze counterrevolutionary global interests and forces. However, it remains to be assessed whether this articulation of the global with the particular constitutes an instrumental appropriation of global forms by Mayan indigenous peoples (cf. Escobar 2008; Mignolo 2002) or an incorporation and assimilation of indigenous politics into mainstream forms, diluting or paralyzing its "revolutionary" potential (see the notion of neo-zapatismo in Leyva Solano 2001).

\section{FRAGMENTARY NOTIONS OF THE STATE}

During debates and interviews for this book with Marxist "revolutionary" intellectuals and politicians, one of the polemical points was the relevance we, as anthropologists, tend to place on the indigenous/local political forms and notions of revolution, instead of reproducing the conventional footprint of revolutionary processes through the conquest of the state. Generally, their point of contention is that revolutionary processes require a centralized power such as the state, able to take quick decisions in order to confront a series of subversive threats to the new revolutionary order.

On the one hand, anthropology may activate a tendency to downplay overarching economic and political dynamics in order to promote a cultural mode that privileges difference, specificity, and identities (cf. Jameson 1998; Santos 2008) and, by doing so, according to socialist intellectuals, reproduces fragmentation rather than generating unity. On the other, anthropology has undertaken particularly significant work in highlighting the consequences of placing the state at the center of the analysis of revolutionary transformations (Lan 1985; Davis 1986; Nugent 1997; Abu-Lughod 2012; Mittermaier 2014; Arbona et al. 2016). Notably, the emphasis on the state may overshadow a series of institutional and political arrangements that may turn out to be instrumental in the definition of the form, purposes, and notions of revolutionary transformation.

Political structures with which anthropologists have traditionally engagedkinship, tribe, lineage-have been associated by revolutionary theorists with the "muck of ages" (Marx and Engels 1976: 53; Shah 2014) that ought to be overthrown by a modern revolution in order to found society anew. The party and the state are supposed to supersede social and political differentiations and the recursive dynamics of exclusion that characterize kinship and tribal relations, often reproduced through a specific anchorage in locality and specific genealogies as mechanisms structuring power, therefore guaranteeing impartiality and democratic integration of all members of society. 
Anthropologists have often signaled the role of tribes, clans, and kinship in shaping political systems "alternative" to the state. For instance, Marcel Mauss (1990) conceived of the gift as a kind of primitive form of social contract generating alliances, forms of reciprocity, networks, and interconnections among groups in nonstate societies. The gift imposed forms of decentralized reciprocity diffused in time that came to work as actual intertribal/interclan bonds replacing the state as a container of centralized power. Highlighting the main differences between the modern notion of state and the Nuer tribal system, Evans Pritchard (1940) emphasized how the Nuer administration of power, with nonspecialist bodies in charge of solving conflicts and administering access to resources and strategies to maintain a political equilibrium through segmentary oppositions, crystallized a kind of "anarchic state" (69). ${ }^{2}$

The same Evans-Pritchard (1954) forecast and even supported a fairly linear inclusion or transition of these nonstate societies into the more modern and effective practices of political operation of the nation-state, replacing some of their traditional forms. Gluckmann's work on rebellion in South-East Africa (1963) also reflected such a linear reading of nonstate societies and particularly the inability of these societies to generate thorough political transformations in the fashion of more advanced states. On the one hand, tribal societies somehow hold a notion of sociopolitical transformation that is not fully mature and that does not fully accomplish processes to liberate one's creative capacities (Wolf 1969). On the other, indigenous and tribal notions of transformation, given their particularity, specificity, and localism, are more prone to be engulfed by global phenomena and regimes of knowledge (Comaroff and Comaroff 2009; Žižek 1997; cf. Holloway 2002).

One of the ideas of this chapter and of this book more generally is to show how that "muck of ages" and traditional political structures have remained central in the shaping of revolutionary transformations and of particular notions of revolutions. This often draws on scholarship that has shown how tribes, for instance, through intertribal alliances and networks of operation, have been instrumental in creating presence, services, and institutionality throughout national territories, shaping "fragmentary" notions of the state and the nation (Khoury and Kostiner 1990; Edgar 2006; Cherstich 2014a; Sneath 2007). But it also draws on anthropological works that have shown how the official and conventional state has been

2. A segmentary system is based on the notion of a society internally differentiated by lineage or tribe and simultaneously held together by a system of shared values. In many anthropological works, the segmentary system is depicted as being characterized by strict rules built around the principle of "me against my brothers, my brothers and me against our cousins; my brothers, cousins and me against the world" (Barfield 1990: 160; see Cherstich 2014a). In other words, the segmentary system remains structured around a series of internal alliances and oppositions between lineages aimed at maintaining a degree of internal equilibrium and even distribution of power, generating a stateless form of "ordered anarchy" (see Abu-Lughod 1989: 281). 
founded on the margins of the social body, often leaving in the hands of tribes, kinship, and lineages a series of political functions, tasks, and services the state was unable to accomplish (Das and Poole 2004; Asad 2004).

In the case of Maoist revolutions, for instance in Peru (Degregori 2012) and particularly in Nepal and India (Shah 2014; Shah and Pettigrew 2018; Pettigrew 2013; Hirslund 2011; Zharkevich 2019), scholars have emphasized a supposedly contradictory articulation between revolution and traditional political forms. Maoist revolutionary practices have been centered on the mobilization of the peasantry and rural groups as the main revolutionary forces, as opposed to the proletariat in the Marxist-Leninist ideology (Mao Zedong 1976). Starting its revolutionary struggle in the countryside, peasant kinship bonds were often instrumental to provide safe houses for recuperation, storage of essentials, and the provision of food. However, if kinship ties are important to sustain the struggle, they are also "politically" dangerous because they depend on the relations of reciprocity, complex dynamics of exchange among clans and lineages, and respect for local chiefs that Maoism is supposed to supersede in the new sociality of the movement. Although Maoism wants to break with village social relations and bring about a new sociality beyond the distinctions of kin, it often remains entangled in the peasant networks and relations that define the countryside and control the territory, producing what Michael Hoffman, in his study of such dynamics in areas of Maoist insurgency in Nepal, calls "partial revolution" (2018).

A similar tension is shown in Alice Wilson's ethnography of Saharawi political life (Wilson 2016). Wilson demonstrates how despite the attempts of the Saharawi Arab Democratic Republic (SADR) to repeatedly displace the tribes and introduce legal and administrative structures supposedly conducive to the consolidation of state sovereignty, the Saharawi experienced a process of retribalization in dynamics of conflict resolution, at times projecting tribal relations as strategic resources in the construction of a revolutionary state power against the Moroccan invasion. As Wilson argues, through the lubricated networks of the tribes, their practices of control of the territory as well as their prelegal dynamics and popular courts, the supposedly fragmentary Saharawi tribes had been able to crystallize a communal revolutionary ethos that prioritized a set of collective interests over factional and divisive intertribal relations. In other words, dynamic, flexible, and less structured forms of political administration as well as a tribal political culture, Wilson suggests, may constitute effective tools motivating individuals and facilitating their participation in revolutionary protests and the fight against an authoritarian regime (see also Caton et al. 2014 on Yemen).

Most of the analyses of revolution have tended to conceal the role of lineage, kinship, and tribe in order to focus on emerging new forms of sociality according to the narratives of salvation, redemption, and emancipation through which 
these events are recounted. In this chapter we not only try to explain the role of local kinship forms and ideas to re-signify revolution according to their logics and forms, but also to signal specific forms of radical political transformation where kinship, tribe, and lineage are not annihilated but on the contrary appear as sources and vehicles of specific revolutionary conceptions.

\section{LINEAGES OF REVOLUTION: THE CASE OF IRAN}

In the following sections, we will attempt to show cases of articulation of different groups and spaces according to nonstate principles, but fundamentally to highlight the role of local political structures such as clans, lineages, and tribes in outlining practices and conceptions of radical transformation derived from their own political logic. In other words, we look at revolution through the framework of tribes and lineages, but we also explore concepts/ideas of revolution developed from the political logics of local tribes and clans. With this objective in mind, we aim to rethink and reconfigure some of the mainstream narratives-liberal, socialist, anarchist-in the conceptualization of revolution and political transformation.

Drawing on anthropological scholarship, in this section we show how the Iranian revolution has been interpreted and reconceptualized through the lens of local political frameworks and rationales that challenge the conventional narratives through which it has been explained. Definitely not as popular among global activists as the Zapatista movement, in that it did not flirt with the modernist tenets of global revolutionary transformation (see Foucault's analysis presented in the next chapter), the main point of contention among leftist and progressive intellectuals around the world was that the Iranian revolution, despite bringing to an end the authoritarian rule of the Shah, also created an Islamic republic based on the principle of velayat-e faqih, the Guardianship of Islamic Jurists. Instead of attempting to free society from all forms of ideology and its apparatuses of domination, since its inception the explicit objective of the Iranian revolution was the creation of a Shía state based on its religious ideology.

In 1953, a British-American-supported coup aimed at the defense of the interests of the Anglo-Iranian Oil Company (later renamed British Petroleum Company) ousted the nationalist prime minister Mossadegh, who was willing to nationalize oil, and reinstated the monarchy of the Shah. Under the auspices of the American government, the Shah proposed modernization and liberalization reforms, disregarding the religious and democratic measures of the Constitution. The reaction of local clerics and of the guilds of shop owners (bazaaris) financing religious celebrations, together with groups of students and Marxist organizations, consolidated a political force and solid opposition to the Shah. Ayatollah Ruhollah Khomeini, the spiritual leader of the resistance, was exiled to 
France from where an active exchange of cassettes and recordings of his sermons steadily fed the resistance. Khomeini returned to Iran acclaimed and received by millions of Iranians. After a brief battle with the forces of the Shah, Iran voted by national referendum to become an Islamic republic and approved a new theocratic-republican constitution whereby Khomeini became the spiritual leader.

Instead of focusing on Islamic principles and notions concerning the new Shi'a state, Mary Elaine Hegland (2014), one of very few foreign anthropologists to have conducted sustained ethnographic fieldwork in Iran across the last four decades, describes how the Iranian revolution of 1979 is conceived among the peasant villagers of Aliabad, a rural area in Fars province in the southwest of the country. Far from framing the revolution in terms of the emergence of a new and universal order, Hegland explains how the political participation of rural villagers in the revolution, their organization, and their political strategies are framed in terms of logics of kinship, descent, and local power disputes. In fact, Hegland explains how the struggle between the Shah and Khomeini is understood and enacted in rural Iran through the framework of the taifeh-keshi, a local understanding of conflict over power and resources among different interest/ descent groups that is transposed from the local to the national scenario. If revolution has been conceived as an event incommensurable with previous forms of organization, Hegland shows how the rules of taifeh-keshi remained not only the sociopolitical principles structuring everyday life but also the framework to comprehend the Iranian revolution and the struggle between the Shah and the revolutionary forces.

The taifeh is a model of political organization that relies on common interests and shared identities, often associated with kinship ties and maintained through forms of help and support to other members of the taifeh. A taifeh can be a kin, but also the clergy or the police. The taifeh-keshi is the process by which the taifeh comes together to take action in a political conflict. The taifeh-keshi is the cultural paradigm and a means that has been regulating political transformations in rural areas for centuries.

In fact, political life in the village revolves around the taifeh-keshi. In every village there is a kin line (taifeh) which, through a system of alliances and due to its ability to maintain political equilibrium, solves conflicts, contributes to wellbeing, and is recognized as the leader of the village. However, the taifeh leadership can be challenged and changed in different circumstances. Hegland describes the pattern of transformation of political leadership in Aliabad in four stages: (1) a kin leader of the village begins to gain wealth and status, mobilizes followers, and creates alliances through marriage, pulling in support; (2) a series of clashes take place between the ascending and the incumbent leaders of the village; (3) the incumbent headman performs an outrageous act seen as detrimental to the political equilibrium and well-being of the village that brings an all-out attack 
and reverts affiliations from the incumbent to the ascending leader; and (4) a final confrontation of forces or struggle takes place where the incumbent is possibly ousted and the unity of the village is re-created under the new leader.

The sequence of events described above has constituted a mechanism of political regulation whereby power and leadership could be repeatedly reconfigured in case of authoritarian acts by the incumbent leader through the intervention and alliance of the other taifehs composing the village. During the years of the Shah, the leading taifeh from Aliabad, the Seyyid, established a bond with the Shah gendarmes interested in enforcing their rule in rural areas. This new alliance ended up impeding Aliabadies from directly intervening in local politics according to the traditional patterns of taifeh alliances that historically had proved able to curtail the authority of the leader and to limit the powers of the kin line, as the Seyyid were now supported by and allied with external forces such as the Shah/ gendarmes. The power of the Seyyid had become unchallengeable.

Politics was no longer conducted at a local level and had instead become a national matter. In the meantime, the youngsters of Aliabad had started studying at the university in Shiraz and local workers commuted to the city by bus. This ended up expanding their networks toward the national level as they associated themselves mostly with supporters of Khomeini and the revolution in opposition to the Shah/gendarmes and the Seyyid family. So while the taifeh of the leader had been forging alliances with external forces such as the gendarmes and the Shah, the other taifeh(s) in Aliabad had become increasingly connected with the revolutionary forces of Khomeini in the region. This expansion of the radius of political operation of the Aliabadies came to reproduce the taifeh-keshi pattern.

The incumbent leader's family (the Seyyid) of Aliabad commits an outrageous act by knifing a local youngster studying in Shiraz and supporting Khomeini. This exercise of excessive force by the leader leads the whole kin and relatives of the youngster's taifeh to mobilize (this time not only locally but also nationally). Villagers are outraged, affiliations are reverted, and a confrontation/war begins, coinciding with the outbreak of the revolution. The taifeh-keshi overlaps with revolution. Once again revolutionary politics is enacted through networking (taifeh-keshi), exchange, and social interactions by maintaining, curtailing, and putting on hold taifeh ties. This is a type of taifeh that has now, however, expanded in scope.

The political conflicts between the Shah and Khomeini and the subsequent transformation are interpreted as the transposition of the taifeh-keshi paradigm from the local to the national level. Instead of Shía symbols and ideologies, or a new model of state government based on the Islamic principle of the Guidance of the Jurist, what motivated villagers' "revolutionary" activities was the kinship culture of taifeh-keshi that produced the local struggle according to strategies and political practices historically anchored locally. The newly emergent set of 
people - the winning taifeh - would then take over political power and everybody would unite under the new leader who has developed forms of affiliation with Ayatollah Khomeini. In other words, despite transposing kinship to a national level, radical political transformation not only is being interpreted but also framed according to the political patterns of kinship outlining an unexpected correspondence and identification between revolution and the paradigm of taifeh-keshi.

\section{STATELESSNESS AND REVOLUTION: UNIVERSALIST PROJECTS AND LOCAL PARTICULARITIES \\ IN THE CASE OF LIBYA}

While in the previous section we explored the understanding of the Iranian Revolution through the kinship framework of taifeh and showed how local notions of kinship may still remain instrumental in the conceptualization of revolutionary transformations, in this section we will look at the central role of tribal mechanisms and conceptions in the definition of Libyan notions of state and of revolution. In fact, with specific reference to the Libyan revolution of 1969, we will explore the possibility and the concept of a "stateless revolution" based on tribal forms of political organization.

Following the Libyan revolution of 2011, scholars and journalists (Lacher 2013; Friedman 2011; Barber 2011) began attributing the failure of the revolution to the lack of national unity and to the lack of understanding of the state by supposedly sectarian tribal herders that weakened the sense of national identity. This stance reproduced both the antithetical relationship between state and nonstate societies we have described earlier, and the notion that the accomplishment of a revolutionary project always requires the state.

In Libya, tribalism does not necessarily constitute a divisive phenomenon limiting national identity (Cherstich 2011, 2014a); on the contrary, it has been instrumental in the constitution of the nation (Evans-Pritchard 1949). During Turkish-Ottoman rule, the dysfunctional policies of the Turkish administration, leading to a high degree of social inequality, drove the tribes to fight against the Ottomans, coalescing by means of intertribal alliances (saff) in order to confront an external threat (Evans-Pritchard 1949). Something similar happened when the Italians occupied Libya at the beginning of the twentieth century and different tribes allied to fight against them, particularly in Eastern Libya (Evans-Pritchard 1949). The same groups that analysts today describe as divisive, always fighting each other, actually unified to create a nation, a Libya free from the invading forces. Indeed, it is fair to say that Libya as a nation, with its current geographical borders, is the result of this tribal anticolonial struggle (Cherstich 2014a; EvansPritchard 1949). In other words, from an historical point of view, in Libya it is the tribes that created the nation. 
Evans-Pritchard-probably our most remote ancestor in the construction of an anthropology of revolution-describes this phenomenon in detail. In particular, he documents a rather counterintuitive overlap in Libya between the Sanusi Muslim fraternity, founded by an illustrious Sufi mystic and scholar of Islamic law and theology, and the nomadic Bedouin tribes in the area of Cyrenaica (Eastern Libya). The decision of the fraternity to operate mostly with rural tribes in marginal areas, providing services to the tribes such as conflict resolution, education, and religious services in exchange for tithes, rent of land, and agricultural/animal products, ended up structuring a theocratic system of fraternity lodges scattered throughout the territory, each corresponding to a tribe or a section of a tribe. This scattered system of lodges reflected the structure of nomadic Bedouin tribes that maintained links with multiple actors and territories, from merchants to colonial officials, providing constantly updated information about what was happening outside of Cyrenaica.

Run by sheiks of the Sanusi order, the lodges accomplished a political and religious function, and they were recognized by tribes as their own lodges and fraternities while simultaneously being articulated to the religious/political center of the Sanusiya in the town of Jaghbub where the Gran Sanusi leader resided. Each lodge was a cult center, but it also was part of a general cult directed through the lodges to the leader of the order, the Gran Sanusi, who in exchange granted his baraka (blessing) to the specific tribe or subsection of a tribe. The lodges, often located in oases and remote areas, also functioned as schools, caravanserais, social centers, law courts, banks, storehouses, poorhouses, and burial grounds.

Even though scholars have problematized some aspects of the analysis of Evans-Pritchard (Ziadeh 1958; Peters 1990), it is fair to say that the Sanusiya with its multiple roles-economic, religious, political-was superimposed upon the tribal system, and it was able, at least to some degree, to unite the different tribes despite their enmities and conflicts, based on a common way of life and a common lineage structure. What ended up maintaining the unity of these structures was a common aspiration to create the conditions for Muslim people to live under their own law, tradition, and government as well as a common hostility to external interferences. The Sanusiya/tribes turned into a proper political force founded on a particular religious-political ethos, able to wage war on foreign invaders and challenge the colonial order but also to materialize a novel form of political organization not necessarily molded to the conventional structure of the state while defying linear narratives of political transformation.

In Libya, tribes have mainly made their living through sheep farming, and their tribal rules have been instrumental in regulating the use of water resources and pastures but also in terms of conflict resolution over access to land and intertribal marriages. Cherstich (2014a: 415) describes how many tribes have a system 
in which each member makes a donation to a common fund on a monthly basis. Such payments constitute a kind of "tax" to create a tribal "social security" fund used to contribute toward the funeral costs of underprivileged members, help those members who have lost their jobs, and / or provide some kind of financial help over a period of time. This role of the tribes in the provision of instrumental, basic services as well as the organization of large territories and resources has positioned them as legitimate sociopolitical actors making up for the failings of the state.

Cherstich (2014a) is adamant in affirming and explaining that these practices of social, political, and juridical intervention by the tribes in everyday matters are not a consequence of their lack of recognition of the legitimacy of the state or of a tribal sovereignty that overrules the state. On the contrary, the intervention of the tribes appears to be a consequence of the inability of the state to operate effectively in certain everyday matters. Somehow, the role, presence, and visibility of the tribe shrink at times when a more solid state is able to accomplish its most basic functions and amplify when the weakness and ineffectiveness of the state becomes palpable and problems, services, and conflicts have to be sorted out the tribal way. In this sense, Cherstich poses tribalism as a system that is not necessarily antithetical to national identity and official state institutions but actually complementary and conducive to them. In such a context, could the tribe or the system of allied tribes provide a platform for the materialization of a specific type of tribal revolution?

With the 1969 revolution, Gaddafi took an ambivalent stance toward tribes. Upon the abolition of the Sanusi monarchy and the affirmation of the revolutionary government of the Free Officers, Gaddafi instituted the so-called Jamahiriya, a type of stateless state. The Jamahiriya system, or "State of the Masses," was an Islamic/Socialist system of popular assemblies that was thought to work without the state, replacing ministries, congress, and representative forms of political decision-making with a set of popular assemblies.

Based on Gaddafi's idea described in the Green Book, the concept of statelessness remained grounded in the conception of political representation as nontransparent and the promotion of "natural" political forms based on the structures and forms of the tribe, kinship ties, and alliances driving practices of direct democracy and participation in everyday politics as opposed to the political specialists and delegates of representative democracies. In other words, the idea of the Jamahiriya, on the one hand, attempts to undermine those universalistic but supposedly artificial and nontransparent political forms such as the party, the ministries, and the government, offering instead the possibility to think about revolution without the intermediate step of the state. On the other hand, the Jamahiriya is presented by Gaddafi himself as another 
type of universalist project, namely the Third Universal Theory of the state-after the capitalist and the communist-which ought to be exported to other countries.

Although the idea of statelessness was instrumentally used by Gaddafi to lead the country according to his will, the concept in itself was highly appealing to Libyans (Davis 1986) - at least in the early years of the revolution. As argued by anthropologist John Davis, the concept of the stateless state is rooted in a form of ideal tribal government from the past, generally referred to by the term alhukuma al 'arabiya-a phrase that can be translated as "Arab government," "people's government," or, better yet, "no government"-an ancestral form of self-rule that predated the creation of nation-states and that plays a fundamental role in the Libyan political imaginary (Davis 1986: 61). If statelessness for people who live in states connotes displacement, Davis (1986) shows how in the case of Libyan tribes, for people who live without conventional forms of government, social order and peace depend on all members of the society knowing well their place in the local political forms. People's sense of status or placement can create a sense of interdependence and solidarity among those tribal members who owe personal loyalty to each other, and Libyans, as argued by Davis, contrasted it with the impersonality of states. Davis describes how Libyans have an image of stateless autonomy in which loyalties are unmistakable and unavoidable. But also such a notion of statelessness remains founded on the tribes' articulation, violent resistance, and revolt against colonial powers. In fact, as we have seen, their territorial control, their alliances, and modalities of occupation of the territory were instrumental in creating a local modality of political administration, operation of justice, and trade.

Gaddafi's ambivalence toward the Libyan tribal system is crystallized in his successive outlawing of tribes that came to be seen as a cause of division and an obstacle to national identity - even though the tribes created the nation (Cherstich 2014a: 409-10). In the nineties, however, Gaddafi appears to change his mind again. He starts praising the importance of tribal leaders - not the tribes-in his political addresses, encouraging the population to follow their decisions and sociopolitical modes of administration. Eventually, Gaddafi creates an assembly of tribal leaders called “The Popular Social Leadership." Gaddafi's praising of the tribal ethos in his speeches is often complemented by a description of the tribes as free peoples who live in tents in the desert and preserve the values and traditions of Libyan society.

On the one hand, from the point of view of official rule, the Jamahiriya is a single tribe that somehow solves the problem of fragmentation and division. On the other hand, after its inception, the Jamahiriya-state is perceived by Libyan tribes as just another tribe (Davis 1986) with which to negotiate, strike alliances, and wage war according to segmentary mechanisms. In this way, tribalism not only survives as a system of law that runs parallel to the state and solves problems 
locally but also incorporates in its own structure and form the notion and apparatuses of revolution as tools to expand, reproduce, and/or strengthen its own logic and system.

Bearing this in mind, it is interesting to note how the tribes played an active role in the revolution of 2011 that brought about the collapse of the Jamahiriya. Though based on the notion of statelessness, in practice Gaddafi's rule ended up generating a "heavy state" that monitored all aspects of the lives of Libyans, mainly through the constant presence of Gaddafi's secret service (Capasso and Cherstich 2014: 384; Capasso 2014). Tribal groups, together with other sections of Libyan society, fought to change this state of affairs. On the one hand, they helped to dethrone Gaddafi not because of an inherent aversion toward the state, but because the Jamahiriya had become a super-state whose tendency to interfere in private matters had to be contained. On the other hand-given that the 2011 revolution did not end up producing an alternative state that could replace the Jamahiriya due to unforeseen complications and foreign interventions - in the post-Gaddafi phase the tribes resumed their role as social agents who help to solve problems locally in the absence of the state (Cherstich 2014a: 418-20).

If, according to Marxism, revolutionary politics ought to be framed in terms of superseding ideologized forms of kinship reciprocity and dangerous tribal hierarchies supposed to reproduce the interests of the leading families, in the case of Libya what begins to be outlined is a typology of revolution as reproducing tribal political structures and mechanisms while rejecting modern colonial notions of political order. What seems at stake in the case of Libya are a set of tribal mechanisms that intervene in everyday life to address the shortcomingsand weaknesses - of official institutions but that also activate a series of tribal alliances and kinship ties in order to overturn an oppressive ruler or an external and communal enemy that is perceived as "just another tribe" centralizing excessive power. It is through these mechanisms and alliances that a tribal notion of revolution is outlined. As we further elaborate in the following section, this leads us to think of and place the revolution in counterintuitive locations other than the usual state-centered framework described earlier.

THE BLUE SHAWL AND THE MULTICOLORED FABRIC:

\section{STATE AND INDIGENOUS ORGANIZATIONS \\ IN THE BOLIVIAN PROCESO DE CAMBIO}

The Bolivian proceso de cambio received unexpected attention from mainstream media and it has mostly been represented by both scholars and journalists through the narrative of the integration of the historically excluded indigenous majority into the nation (Postero 2017; Goodale and Postero 2013; Regalsky 2010; 
García et al. 2014; Soruco et al. 2014; Svampa and Stefanoni 2007; Canessa 2012; Zegada et al. 2011). In general the state, its economic and social policies, and its leadership have been positioned at the center of the analysis of Bolivian revolutionary transformations. While in the previous section we have explored notions of nation anchored in segmentary systems as well as ideas and practices of revolution crystallized by the mechanisms and notions of tribal political organizations, what we outline in this section is a series of political loci, strategies, and spaces of popular sovereignty challenging the notion and role of the state and the party as the centralizing and leading agents of revolutionary transformations.

During the upheavals that marked the beginning of the proceso de cambio, political observers were faced with rather unusual dynamics. The leaders of local unions and neighborhoods committees accustomed to negotiating with official institutions and party vanguards were pushed aside and replaced in political and military decision-making by hundreds of articulated popular assemblies and associations (Mamani 2010; Zibechi 2006). Grouping together a few families, these assemblies were involved in the daily local administration of popular markets, the issuing of sales licenses, and the control, safety, and security of marginal neighborhoods, replacing the state in the exercise of its most basic day-to-day functions and the provision of basic services.

The idea of a popular/indigenous political form made up of articulated but nonintegrated associations, each maintaining a degree of autonomy and political decision-making and spanning multiple territories, had long been an aspiration and practice of the indigenous sectors of Bolivia. Clearly differentiated from the idea of a political party, in the 1990s indigenous and popular sectors created the so-called "political instrument," a strategic political organization conceived as a "bird born of multiple eggs" (cf. Arguedas [1966] 2009), a "son / daughter" (García Yapur et al. 2014: 92) of the multiple articulated peasant and indigenous associations, with the intention to avoid both the delegation of authority to a specialist political elite and the consolidation of the vertical structure of a political party. Often perceived by external observers as lacking discipline and organization (Lazarte 1991), the political instrument's absence of secretariats (Anria 2009) and bureaucracy guaranteed forms of direct political access to a multiplicity of local organizations, often maintaining different political stances and aspirations without having to renounce their local political forms and logics and adopt those imposed by the supposedly universal rules of the official political system.

Both the popular assemblies as a system of articulated microgovernments (Mamani 2010; Zibechi 2006) playing a strategic role in El Alto's upheavals and the "political instrument" as a network of indigenous, peasant, and popular organizations begin to outline another type of sociopolitical space and logic of organization. Scholars (Arbona et al. 2016) have referred to this specific modality 
of organization in terms of a "fabric" of "interlaced" groups, articulated but not integrated, a set of differentiated and autonomous segments that are nevertheless thought to be complementary parts of a functioning political body (cf. Bastien 1985, see also García Yapur et al. 2014).

In their description of the Feria 16 de Julio in El Alto, the largest popular market in Bolivia and one of the most important of the region, Arbona et al. (2016) are impressed by the lack of a union committee or a governing body in charge of settling internal conflicts, dealing with formal institutions, or negotiating with external partners willing to invest in this booming commercial area. The Feria 16 de Julio functions by means of the articulation of hundreds of associations of popular traders, producers, and neighbors that have been expanding their radius of operation and reproducing their organizational forms and practices well beyond the urban boundaries. Within each association you find several "secretaries of relations" (secretarios de relaciones) who are in charge of weaving or consolidating relations both with the other associations constituting the Feria and with a number of external groups, from suppliers to institutional actors. This system constantly strives to avoid the concentration of power in one of the segments / associations; internal mechanisms are activated to split a segment in two if its growth and power begin to challenge the political equilibrium. This "fabric" of articulated segments avoids the delegation of power and sovereignty to a transcendent power holder and the exercise of forms of external authority. The fabric remains coterminous with the community, allowing each family to play an active role in the local decision-making processes while maintaining a constant rootedness in local realities. According to Arbona et al., the dynamics of the fabric not only enable them to overcome the hierarchical and sectorial structure of the party or union, with their narrative of increasing unification of salaried labor, but also to outline strategic modalities of decision-making, organization, and control of territory tangential to the conventional ones defined by the state.

If for some left-leaning intellectuals and politicians of the Morales administration the proceso de cambio could be identified with the consolidation of a stronger and more inclusive state capable of consolidating a firmer grip on the national economy and the territory, for the indigenous and popular sectors the radical transformation lays in the possibility of affirming and expanding a fabric of diverse and articulated segments. Such a fabric has always been there, often camouflaged beneath semblances of more familiar political formations, from the trade union to the cooperative (García Linera 2008). However, its symbolic emergence, its capacity to articulate groups across territories, has brought to the forefront a counterintuitive political terrain molded on the segmentary principles of Andean political formations that have been able to reproduce themselves beyond the circumscribed and parochial territory traditionally assigned to kinship lineages and ethnic groups. While the state appears to be characterized by a centripetal force defining the political mechanisms and their articulation with the territory through 
a vertical structure of regional governments, provinces, and municipalities, the fabric outlines a tendency to penetrate a multiplicity of territories simultaneously and a capacity to generate processes of connection of different groups and spaces but no integration. While the state constitutes a transcendent structure representing the nation, the fabric remains coterminous with local organizations. If the canonical notion of revolution has connoted an emancipation from traditional and indigenous political forms, the proceso de cambio can be perceived from the point of view of Aymara indigenous and popular sectors as the transpositionand expansion (see chapter 6) - of a series of "own" political principles and logics toward the core field of politics.

Despite the rhetoric of the revolutionary government in Bolivia describing itself as a government of social movements, the political projects of the revolutionary state and those of the indigenous sectors have been slowly but clearly diverging (Postero 2017). The revolutionary state has been increasingly building its identity as a powerful and paternalistic figure that redistributes the substantial revenues from the exploitation of hydrocarbons to underprivileged indigenous communities while attempting to co-opt them into the proper political path. Scholars have highlighted the consolidation of a controlling and overarching state capable of bending social and indigenous movements to its will (Zegada et al. 2011) but also the emergence of unexpected dynamics of negotiation, articulation, and overlap between the state and local political formations (Soruco et al. 2014; Arbona et al. 2016). If in some cases state narratives and co-option attempts have been successful, indigenous popular sectors have been appropriating state revenues and policies to strengthen their own rules, political spaces, and decision-making capacities (Arbona et al. 2016). At the inception of Evo Morales's government in 2006, the member of an association of female fishmongers from an Aymara community on the shore of Lake Titicaca settled in El Alto commented:

Look, Evo is like the husband marrying us all, marrying Bolivia the day of the elections. He has got his task, we have got ours. He ought not to meddle with us, he ought not to tell us what to do. We have already learned what we have to do. $\mathrm{He}$ ought to be there making sure the foreigners and the qaras [white Bolivians] don't disturb. For all the rest, we are taking charge of it. (Gutierrez 2015: 40; our translation)

Although framed in terms of a marital relation, the relationship of the fishmongers with Evo/the state is not at all identifiable with a type of romantic, unconditional love. Marriage among Aymara popular sectors is never a romantic confluence of forces and destinies, but rather the tense and sometimes conflictive encounter of two autonomous and articulated elements. This process entails a reciprocal and gradual leveling of differences in order to create a state of equilibrium between the two and a horizontal relationship with no delegation of decision-making and constant leveling of excesses. 
From the point of view of indigenous and popular sectors, what "revolution" brings about is not only (or not so much) the conquest of the state-or the withering away of the state-but the emergence and crystallizing of a fabric of articulated but different groups, associations, and lineages with a degree of autonomy, another political terrain constantly attempting to appropriate and level the state, to limit its power, and its tendency to disregard or engulf the fabric. Such a fabric is not vertically and hierarchically connected to the state or inserted in the latter's political logic - as in the case of the relationship between the state and the trade union. "Revolution" not only brings about a "new," sovereign, and segmentary political structure but actually inserts the state into a new political horizon and segmentary logic where it is constantly "appropriated" and "leveled," as per the forms of operation of the segmentary system. In other words, revolution does not imply here the turning toward a "new" luminous political horizon embodied by the conquest of the state but rather the turning "back" toward the segmentary forms of Andean polities activating, potentiating, and expanding them not in order to integrate them into the state but to place them in a horizontal relation of force with it.

\section{CONCLUSION}

In this chapter, we have looked at what happens to the conventional notions of politics and the state when revolution is seen through the logics of kinship, tribalism, and lineage. We have also attempted to outline what kinds of surprises from the standard European notion of revolution we are faced with when thinking of revolution through segmentary logics and ideas. In the first place, we have attempted to locate a tension or identify differences between the notion of the state as a unitary, universal political institution and the fragmentary political notions of tribal / kinship / indigenous polities. On the one hand, the state presupposes the monopoly and concentration of power, legitimacy, and coercion exercised by bodies separated from society and specialized in the administration of justice, law, and education. On the other hand, in the examples drawn from Iran, Libya, and Bolivia we have experimented with notions of power as distributed and dispersed through the social body and coextensive with the community, where the universal and unitary notion of the state comes to be inserted in the fragmentary and particularistic local logics. These fragmentary logics of the state remain grounded in the articulation but not integration of multiple political structures and in the attempt to constantly curtail and level power to avoid an excess of concentration.

These ideas and divergences between state and nonstate are in direct correspondence with a notion of revolution that is conventionally interpreted as based on the overcoming of local particularities, the emergence of new social units, and the centralization and hierarchization of power in order to channel the old society 
toward a transcendent new political horizon disentangled from the immanence of present, quotidian life. In this chapter we have addressed processes and ideas of revolutionary transformation centered on the visibilization, recognition, and reproduction of local political forms or on the transposition of particularistic notions of the political from the local to the national level. While in the case of Libya we have foregrounded a kind of revolution (1969) attempting to do away with the state from the very beginning on the political basis of tribalism, in Bolivia we have outlined a revolutionary process connoted by a deepening of a fabric of associations and relations while avoiding freezing them into forms of transcendent domination (i.e., a state). In general, this has enabled us to showcase a set of revolutionary, political transformations as operating step by step, coterminously with society, without an ultimate political project or transcendent horizon defined a priori to aspire to. 